ORIGINAL ARTICLE, MEDICINE

\title{
Development of Bioethics and Clinical Ethics in Bulgaria
}

\author{
Silviya S. Aleksandrova-Yankulovska \\ Department of Public Health Sciences, Faculty of Public Health, Medical University - Pleven, Bulgaria
}

\author{
Correspondence: \\ Silviya S. Aleksandrova-Yankulovs- \\ ka, Department of Public Health \\ Sciences, Faculty of Public Health, \\ Medical University - Pleven, 1 Kli- \\ ment Ohridski St. \\ 5800 Pleven, Bulgaria \\ E-mail: silviya_aleksandrova@ \\ hotmail.com \\ Tel: +35964884196
}

Received:12 Jan 2016

Accepted: 06 Oct 2016

Published Online: 09 Jan 2017

Published: 27 March 2017

Key words: bioethics, Bulgaria, clinical ethics, clinical ethics consultation, METAP methodology

Citation: Aleksandrova-Yankulovska SS. Development of bioethics and clinical ethics in Bulgaria.

Folia Medica 2017;59(1):98-105. doi: 10.1515/folmed-2017-0015
Background: Bioethics and clinical ethics emerged from the classical medical ethics in the 1970 s of the $20^{\text {th }}$ century. Both fields are new for the Bulgarian academic tradition.

\begin{abstract}
Aim: The aims of this paper were to demarcate the subject fields of medical ethics, bioethics, and clinical ethics, to present the developments in the field of medical ethics in Bulgaria, to delineate the obstacles to effective ethics education of medical professionals, and to present the results of the application of an adapted bottomup methodology for clinical ethics consultation in several clinical units in Bulgaria.

Materials and methods: Extended literature review and application of an adapted METAP methodology for clinical ethics consultation in six clinical units in the Northern Bulgaria between May 2013 and December 2014.

Results: Teaching of medical ethics in Bulgaria was introduced in the 1990s and still stands mainly as theoretical expertise without sufficient dilemma training in clinical settings. Earlier studies revealed need of clinical ethics consultation services in our country. METAP methodology was applied in 69 ethics meetings. In 31.9\% of them non-medical considerations affected the choice of treatment and 34.8\% resulted in reaching consensus between the team and the patient. Participants' opinion about the meetings was highly positive with $87.7 \%$ overall satisfaction.
\end{abstract}

Conclusion: Development of bioethics in Bulgaria follows recent worldwide trends. Several ideas could be applied towards increasing the effectiveness of ethics education. Results of the ethics meetings lead to the conclusion that it is a successful and well accepted approach for clinical ethics consultation with a potential for wider introduction in our medical practice.

\section{BACKGROUND}

The term "medical ethics", as initially introduced, refers to the rules of etiquette developed to regulate the professional conduct. Thus traditional medical ethics is focused on the duties of the good physicians. However, ethics refers not only to the rules, customs, and beliefs of a society. It also encompasses the scholarly efforts to articulate and analyze those rules, customs and beliefs. In the decades after World War II medical ethics took a turn as medical science advanced and medical interventions became increasingly technical. In the light of increased opportunities to prolong life traditional duties were challenged because it was no longer clear what is benefit and what is harm. New intellectual resources were summoned to struggle with the new questions. Theologians, philosophers, and lawyers, who struggled with the same dilemmas as physicians, were invited into these discussions. ${ }^{1}$ Bioethics was born and developed on the fundaments of "the old medical ethics" but facing unprecedented problems and embracing many more participants. The new field needed completely new analytic approach. In the Introduction to the 1995 revised edition of the Encyclopedia of bioethics, Warren Thomas Reich defined bioethics as "the systematic study of the moral dimensions - including moral vision, decisions, conduct, and policies - of the life sciences and health care, employing a variety of ethical methodologies in an interdisciplinary setting." Bioethics is a particular field of human inquiry, the insertion of ethics and the life sciences but also an academic discipline; a field that ranges from individual dilemmas faced by healthcare professionals to the choices faced by citizens and legislators at the level of public health. ${ }^{2}$

As the field has developed, it has become clear 
that because of the range of diversity of bioethics issues, more than one methodology is needed. Different areas of inquiry are distinguished - theoretical ethics, clinical ethics, regulatory and policy bioethics, cultural bioethics. In practice, these fields often overlap.

The term "clinical ethics" was introduced in the USA. It refers to the everyday moral decision making of those caring for patients and it is focused on the individual case. As a next step, clinical ethics consultation was developed.

Clinical ethics consultation is defined as "a service provided by an individual or group to help patients, families, surrogates, health care providers, or other involved parties to address uncertainty or conflict regarding value-laden issues" that arise in specific clinical cases. ${ }^{3}$

\section{AIM}

The aims of this paper were to present the developments in the field of medical ethics in Bulgaria, to delineate the obstacles to effective ethics education of medical professionals, and to present the results of the application of an adapted bottom-up methodology for clinical ethics consultation in several clinical units in Bulgaria. The aims are consequent and cumulative in order to present the stages of development and recognition of bioethics into the practical field it was initially designed to serve, i.e. clinical practice.

\section{METHODOLOGY}

The review of bioethics development in Bulgaria is based on an extended literature review and personal 16-year experience, observation and active participation in the development of the field by the author. The second part of the paper presents the application of an adapted METAP methodology for clinical ethics consultation in 6 clinical units in the Northern Bulgaria in the period May 2013 - December 2014. The methodology is innovative for the country and Eastern Europe.

The methodology aims at enabling physicians to identify and solve ethical dilemmas in their practice even if they did not have specific training in bioethics. The following specific instruments were developed in relation to the implementation of the methodology: validated translated protocol of ethics meetings, validated translated information checklist, adapted informational brochure, PowerPoint presentation of the methodology for the preliminary meetings with the personnel, originally developed questionnaire for interview with the personnel at the preliminary meetings, questionnaire for extraction and analysis of information of ethics meetings and feedback self-administered questionnaire.

The informational brochure was designed to provide the theoretical framework for ethical decisionmaking based on principlism as a dominant ethical theory. It was presented to the personnel in the chosen wards. At these preliminary meetings, interviews with the personnel were conducted to identify their experience in ethical decision-making and possible obstacles in the implementation of the programme. One team member had passed more extended training to work with the instruments and to facilitate the process of ethical decision-making. The organization of the ethics meetings was preceded by collection of information through the information checklist covering three main information areas of interest: treatment and care, patient characteristics, and parameters of social environment and aiming to reveal any gaps in the available information. Informational brochure was then applied at the discussions over treatment alternatives and the process was documented in the protocols of ethics meetings. The participants in the meetings were asked to fill in feedback selfadministered questionnaire (consisted of 17 questions in 4 thematic fields) which achieved $81 \%$ response rate. ${ }^{4}$ All documents were collected and subjected to thorough analysis through the questionnaire for extraction of information of ethics meetings (consisted of 47 questions). The implementation of the methodology and its instruments were approved by the institutional ethics committee.

\section{RESULTS AND DISCUSSION}

Developments in Bulgaria

There are several corner stones in the more recent history of medical ethics development in Bulgaria. In 1904 Bulgarian Physicians' Association adopted the first ethical guidelines for physicians. In 1918 with the establishment of the Medical Faculty at the University of Sofia deontology was officially included in the undergraduate curriculum in medicine. The programme was focused on legal norms governing the profession and professional etiquette.

In the communist period (1945-1989) deontology teaching was excluded from the curriculum as separate subject. Some of the ethics topics were included in the subject "Organisation of health care" and deontology (medical law) was assigned to forensic medicine. 
In 1973, the Moral Code of Bulgarian physicians was adopted and in 2000 - the Code of Professional Ethics of Physicians (renamed in 2013 to Code of physicians' professional ethics). In 1988 Prof. Vasil Prodanov, the former Director of the Institute of Philosophy at the Bulgarian Academy of Science, published the book "Bioethics" which was considered as the first monograph on the topic in the European ethical literature. ${ }^{5}$

Medical Ethics was introduced as a separate subject in undergraduate medical education in 1991. Several textbooks were published by teams of the different medical universities in the country. In 2011, the Faculty of Philosophy at Sofia University "St. Kliment Ochridski" initiated the first master degree programme in bioethics under the title "Integrative Bioethics".

Although ethics in Bulgaria developed much during the last decades, still it has been associated with deontology. Laymen as well as many health professionals continue to think that ethics is mainly about the relationships between the physician and the patient and about developing rules of professional conduct. This conceptual framework is not rejected in contemporary ethics but new issues are in focus: development of codes of research ethics, regulations for the protection of human subjects in research, the social and moral consequences of research, efforts to formulate public policy guidelines for clinical care, allocation of health care resources, and patient access to health care services.

In Bulgarian Health Act adopted in 2004, chapter 7 , part IV is dedicated to medical research involving human subjects. ${ }^{6}$ The requirement for prior approval of the research protocol by an Ethics committee is set. This requirement is also stated in the Law of Medicinal Products in human medicine (2007), according to which every medical institution conducting research should establish ethics committee. ${ }^{7}$ Following the law, 195 research ethics committees were officially registered. Ethics committees have been established in scientific institutions performing experiments, in medical universities and hospitals as well as in all medical professional bodies on national and regional levels: Bulgarian Physician Association, Bulgarian Dental Association, and Bulgarian Association of Health Professionals. On national level, an Ethics committee about transplantation is functioning. As a whole, however, these committees are focused on research ethics and professional ethics, their members rarely have specific ethics training and they do not provide ethics consultation on clinical ethical dilemmas.

In relation to the public debate activities we have to point out philosophical journals and the media where ethical issues are discussed since a specialized national bioethical journal is missing yet.

Several ethics conferences were organized by the Bulgarian Academy of Science during the years (Table 1).

On April 8, 2014, Silviya Yankulovska started the initiative "Day of Bioethics" in the Medical University - Pleven. The first two events were dedicated to research ethics and human rights in

Table 1. Ethics conferences organized by the Bulgarian Academy of Science

\begin{tabular}{|c|c|}
\hline Year & Ethics conference topic \\
\hline 2004 & $\begin{array}{l}\text { Ethics in Bulgaria - yesterday, today and } \\
\text { tomorrow }\end{array}$ \\
\hline 2005 & Morality in Bulgarian politics \\
\hline 2006 & $\begin{array}{l}\text { Morality and socialization of children and } \\
\text { youngsters in Bulgaria }\end{array}$ \\
\hline 2007 & Ethics in Bulgarian health care \\
\hline 2008 & Morality in Bulgarian media \\
\hline 2009 & Ethics in Bulgarian economy \\
\hline 2010 & $\begin{array}{l}\text { National identity - contemporary social } \\
\text { context and ethical framework }\end{array}$ \\
\hline 2011 & Ethics in Bulgarian science \\
\hline 2012 & Ethics in Bulgarian legal system \\
\hline 2013 & $\begin{array}{l}\text { European ethical standards and Bulgarian } \\
\text { standards }\end{array}$ \\
\hline 2014 & $\begin{array}{l}\text { Environmental ethics and sustainable deve- } \\
\text { lopment in Bulgaria }\end{array}$ \\
\hline 2015 & $\begin{array}{l}\text { Morality and ethics of solidarity in contem- } \\
\text { porary society }\end{array}$ \\
\hline
\end{tabular}

Source: Department of ethical studies. Institute for the study of societies and knowledge - BAS. Available in Internet from: https://ethicsissk.wordpress.com $/ .^{8}$

patient care. The 2016 topic was focused on aging ethics. The coming Day of bioethics 2017 will take place under the motto of ethics in practice.

Several international round tables were organized by the Bulgarian Centre for Bioethics: 2010 - "Organ Donation in Europe: Challenges, Opportunities and Exchange of Good Practices", 2015 - "Bioethical standards in translational medical research". 
The Foundation for Development of Justice organized four national bioethical conferences: 2013 - "Body and dignity", 2014 - "Ethical and legal borders of health care", 2015 - "The human being in bioethics and biolaw regulations". The tradition was continued in 2016 under the motto "Bioethics and biolaw - modern practices and politics for the future".

OBSTACLES TO EFFECTIVE ETHICS EDUCATION OF MEDICAL PROFESSIONALS

Although teaching of medical ethics has been introduced in Bulgaria for more than two decades already, there are obstacles to its effective outcomes.

The comparative analysis of ethics teaching programmes in Bulgarian medical universities has shown similar topics and number of teaching hours. ${ }^{9}$ The courses are scheduled in the first years of medical studies when students still lack clinical experience. There are no other philosophical disciplines in the medical curriculum which makes the understanding of bioethical concepts difficult and hinders their practical application.

Additionally, there is a disproportion of teaching hours between different medical specialties. Due to the overwhelming programmes of medical students, medical ethics courses usually cover only 30 academic hours. Programmes for nurses, midwives, laboratory technicians and health inspectors at different educational levels all together offer more extensive ethics education. In clinical practice, though, the prime responsibility for decision-making lays with physicians.

The acceptance of ethics in medical practice is controversial. There is still wide misunderstanding over the subject of medical ethics only in the framework of the above mentioned definition of medical ethics. Thus medical professionals are unaware of the possibilities for practical support in day-to-day ethical decision-making that bioethics education can offer.

Ethics education stands mainly as theoretical expertise and there is insufficient motivation for application of dilemma training in clinical settings (no "ethical climate").

Additionally, there is a lack of cooperation between the universities. Every university uses different study materials and educational approaches. The information for scientific activities in the area of bioethics often is insufficient and the collaboration between professionals, working in the field, is doomed to failure.
APPLICATION OF AN ADAPTED BOTTOM-UP METHODOLOGY FOR CLINICAL ETHICS CONSULTATION IN BULGARIA

Bearing in mind the problems of achieving effectiveness in bioethics education in Bulgaria and the fact that many of the practicing physicians did not pass any bioethics course but still they rely mainly on their own judgement in cases of ethical dilem$\operatorname{mas}^{10,11}$, the introduction of clinical ethics consultation services is justifiable. Empirical data of two innovative surveys on the experience of Bulgarian physicians in ethical decision-making confirm the positive attitude towards the ethics consultation. However, the lack of trained clinical ethicists in the country and the predominant conservatism of medicine as profession to outside personal involvement in the decision-making process suggest that bottom-up models of clinical ethics consultation would be more appropriate to the Bulgarian context than the classical top-down approaches.

The starting point of the bottom-up model is the moral conflict at the bedside or more precisely, the need of support in a situation where too much is asked of the individual conscience of a stakeholder. The bottom-up model starts with an individual solution-oriented approach instead of a norm-based top-down approach where the governing bodies (or ethics committee) provide ready-made instructions for behavior at lower levels. ${ }^{12}$

A specific bottom-up approach for clinical ethics consultation is the METAP project. It aims at improving the ethical quality of clinical decisions and relies on enhancing the ethical competence of the clinical staff involved in making these decisions by providing knowledge through material, procedures and instruments. After a period of pilot implementation, METAP is now working in various clinical settings in seven institutions in Switzerland. ${ }^{13}$

The METAP methodology was adapted for Bulgarian settings by the author of the present article and it was introduced in selected clinical units in Bulgaria. Sixty nine ethics meetings took place in the study period (Table 2). The clinical units were chosen on the basis of the following criteria:

- Representation of different clinical specialties;

- Representation of in-patient and out-patient units;

- Availability of at least one team member with bioethics training or expertise in psychology.

General characteristics of ethics meetings were: - The majority of the meetings (44.9\%) involved 4 participants.

- The average duration of a meeting was 36 minutes 
Table 2. Ethics meetings organized in selected clinical units in Bulgaria with the application of adapted METAP methodology (May 2013-December 2014)

\begin{tabular}{clcc}
\hline \multirow{2}{*}{ № } & \multicolumn{1}{c}{ Clinical unit } & \multicolumn{2}{c}{ Ethics meetings } \\
\cline { 3 - 4 } & & $\mathrm{n}$ & $\%$ \\
\hline 1. & $\begin{array}{l}\text { Specialized } \\
\text { Cardiological } \\
\text { Hospital, Veliko } \\
\text { Turnovo }\end{array}$ & 10 & 14.5 \\
2. & $\begin{array}{l}\text { Comprehensive } \\
\text { Oncological } \\
\text { Center, Vratsa }\end{array}$ & 32 & 46.4 \\
3. & $\begin{array}{l}\text { Center of } \\
\text { Reproductive } \\
\text { Medicine, Varna }\end{array}$ & 2 & 2.9 \\
4. & $\begin{array}{l}\text { Neonatology } \\
\text { ward, University } \\
\text { hospital, Pleven }\end{array}$ & 4 & 5.8 \\
5. & $\begin{array}{l}\text { Pediatric ward, } \\
\text { University } \\
\text { hospital, Pleven }\end{array}$ & 10 & 14.5 \\
6. & $\begin{array}{l}\text { Medical center } \\
\text { Galileo, Pleven }\end{array}$ & 11 & 15.9 \\
Total & & 69 & 100.0 \\
\hline
\end{tabular}

$(\mathrm{x}=36.09 \pm 20.506)$ and it was judged as sufficient by $81 \%$ of the participants.

- Most of the cases requiring ethics meeting (59.4\%) were organized in patients between 50 and 79 years of age.

- Leading diagnoses requiring ethics meetings (47.8\%) were different types of cancer.

- Participants in all meetings add up to a total of 286 (Table 3). In all meetings a physician was involved and in some cases also a consulting physician. In 43 meetings $(15.5 \%)$ the physician was in their role of a head of the ward/clinics. Physicians chaired all meetings. In 28 meetings $(9.8 \%)$ other health professionals (nurses and midwives) were involved. A psychologist took part in 43 meetings $(15.5 \%)$. Patient's parents were involved in 38 meetings $(13.3 \%)$. The patient was directly involved in 25 meetings.

- The most common reason to organize ethics meeting was "choice of treatment among available alternatives" (13.9\%) followed by "accusations on the side of the patient/relatives/personnel in inadequate attitude or treatment" (23.2\%) and "disagreement
Table 3. Characteristics of the participants in ethics meetings

\begin{tabular}{llcc}
\hline Year & \multicolumn{1}{c}{ Participants } & $\mathbf{n}$ & $\mathbf{\%}$ \\
\hline 1. & Patient & 25 & 8.8 \\
2. & Treating physicians & 48 & 16.8 \\
3. & Physician on duty & 6 & 2.1 \\
4. & Consulting physician & 19 & 6.6 \\
5. & Head of clinic/unit & 43 & 15.1 \\
6. & Psychologist & 43 & 15.1 \\
7. & Nurse/midwife & 28 & 9.8 \\
8. & Spouse & 16 & 5.6 \\
9. & Mother/father of the & 38 & 13.3 \\
& patient & 15 & 5.1 \\
10. & Other relatives* & 5 & 1.7 \\
11. & Others** & 286 & 100.0 \\
Total & &
\end{tabular}

between the patient/the relatives and the team about the treatment" (17.4\%) (Fig. 1). These were different conflicts including rude and humiliating behavior on the side of the patient and relatives.

Most of the ethics meetings were related to patients of the so called "typical borderline type". These are patients with excessive burden related to the treatment $(73.9 \%)$, risk of complications $(81.2 \%)$, considerable need of care $(55.1 \%)$, expected fast decline in the health status (52.2\%), long-term unfavourable prognosis including a lethal outcome $(78.2 \%)$, and progressive deterioration of quality of life $(47.8 \%)$.

As for the results of the ethics meetings (Fig. 2), in $34.8 \%$ consensus between the team and the patient was achieved; in $27.5 \%$ the situation was clarified inside the team and with the patient/relatives, in $15.9 \%$ the situation was clarified inside the team. Thus the results of ethics meetings are in accordance with the reasons to organise them where in $31.9 \%$ we found difficulties to choose between available treatment alternatives. In the cases where patients were not directly involved in the meetings subsequent discussions and information had to be provided to them. 


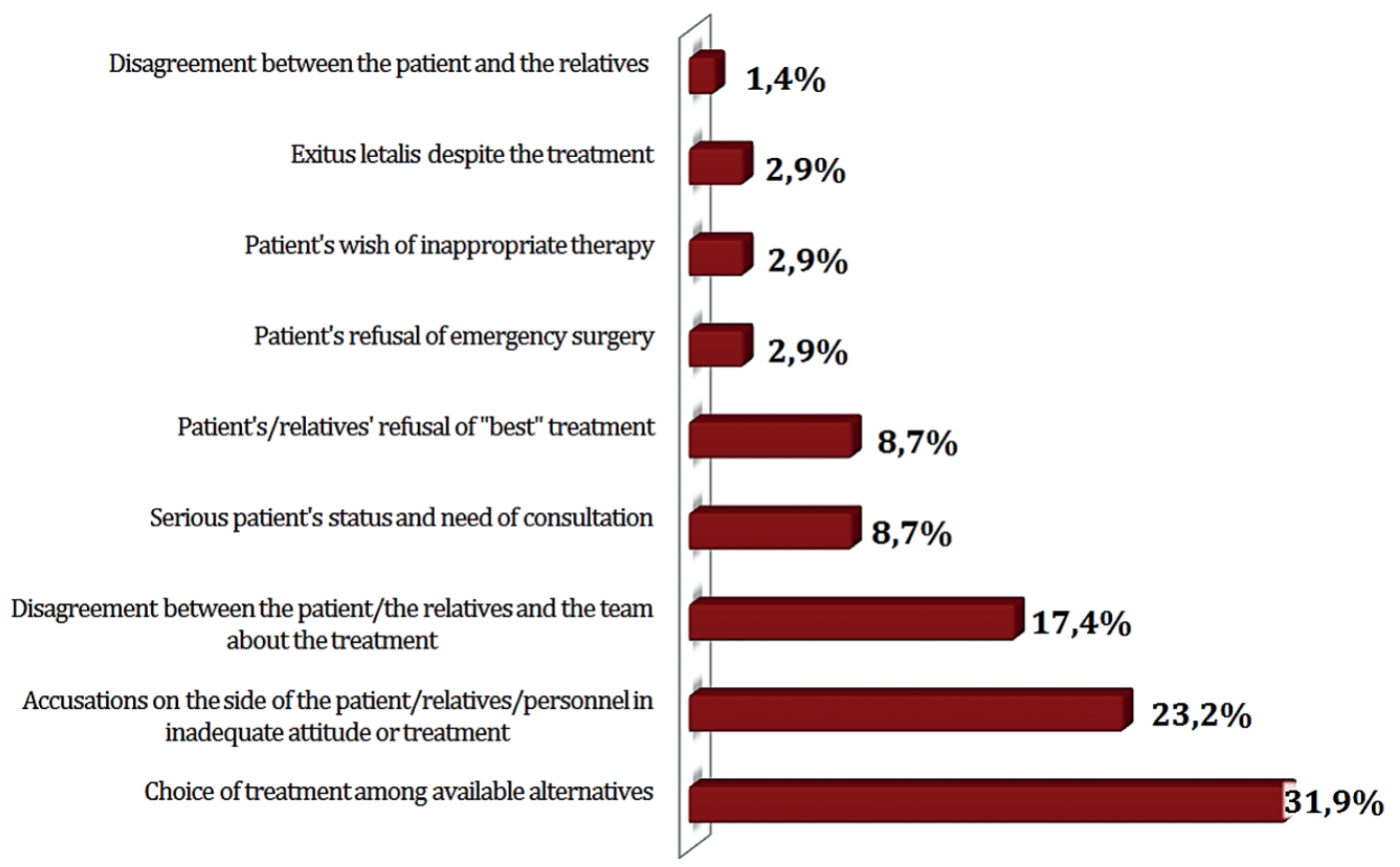

Figure 1. Reasons to organize ethics meetings.

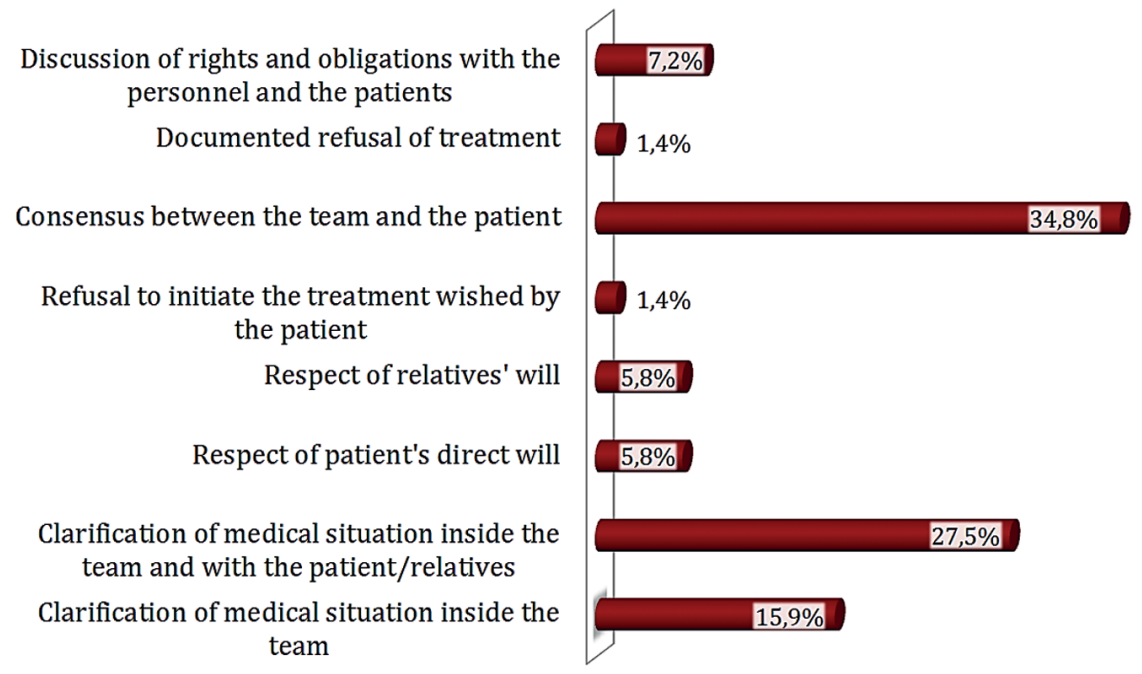

Figure 2. Results of ethics meetings.

In 28 meetings (40.6\%) the decision was final and re-assessment was not planned. In 59.4\%, however, re-assessment was planned. These were cardiological cases, where the routine control check-ups could be combined with new ethical discussions.

The opinion of the participants about the structure and outcome of ethics meetings was highly positive: - According to $95.4 \%$, the moral problem was well defined.

- According to $93.3 \%$, values and preferences of the patient were respected.

- According to $95.4 \%$, all parties could express freely their opinion during the meeting.

- $87.7 \%$ of participants expressed overall satisfaction with the meeting.

- $85.6 \%$ of participants assessed the meeting as useful. Most significant benefits recognized by the participants (Fig. 3) were "better clarification of the problem" (26.4\%) and "better communication in the team" $(20.8 \%)$.

- According to $90.8 \%$ of the participants the moral problem was fully or partially resolved at the meeting. 


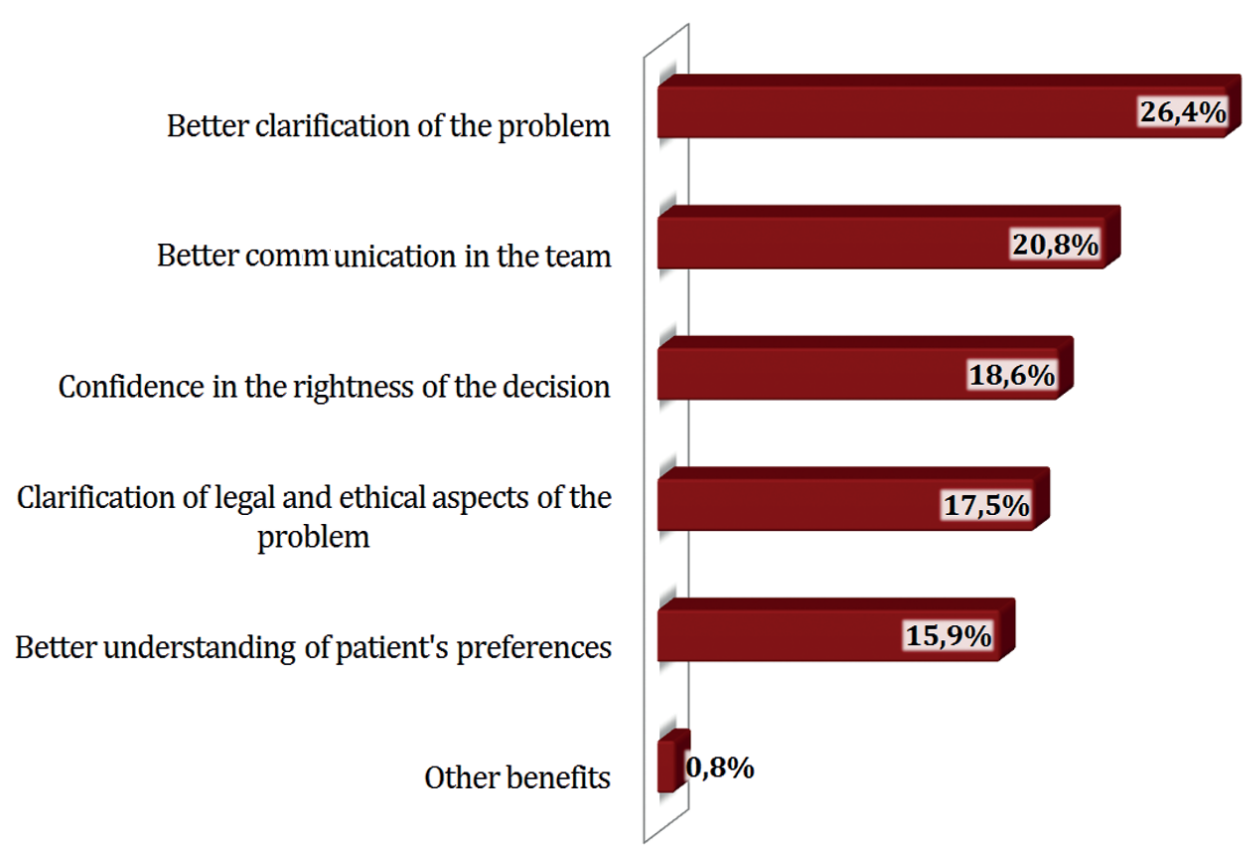

Figure 3. Most significant benefits of the meetings.

\section{CONCLUSION}

Development of bioethics in Bulgaria follows recent trends in the world and Europe. Several ideas could be applied towards increasing the effectiveness of ethics education. The establishment of a National Association on Bioethics could improve the cooperation between educational institutions and experts in the field. Foundation of a national bioethics journal would contribute for development of bioethical studies.

Results of the application of the adapted METAP methodology in Bulgaria lead to the conclusion that it is a successful and well accepted approach for clinical ethics consultation with a potential for wider introduction in the medical practice. Bulgarian physician association in collaboration with hospitals' management can create conditions for the introduction of the methodology and to encourage its application. On the level of medical universities courses on ethical decision-making in clinical practice can be introduced in last years of medical studies. Post-graduate courses should be offered for continuous bioethics training.

\section{REFERENCES}

1. Jonsen A. The Birth of Bioethics. Part I: Bioethical Beginnings: The people and places. New York, Oxford: Oxford University Press; 1998:3-34.

2. Post SG. Bioethics. In: Encyclopedia of Bioethics. $3^{\mathrm{d}}$ edition. USA: Macmillan Reference; 2004:278-87.
3. Aulisio MP. Ethics consultation: Is it enough to mean well? Healthcare Ethics Committee Forum 1999;11(3):208-17.

4. Aleksandrova-Yankulovska S. Clinical ethics consultation - attitude towards the introduction, training in ethical analysis and application of methodology for decision-making in clinical practice [dissertation]. Pleven: MU-Pleven; 2015. [Bulgarian]

5. Prodanov V. Boiethics [Internet]. Sofia: Science and Art; 1988:253. Available in Bulgarian from: http:// www.old-philosophy.issk-bas.org/books/Prodanov. Bioethics.pdf

6. Bulgarian Health Act. Promulgated, State Gazette No. 70/10.08.2004.

7. Law of medicinal products. Promulgated, State Gazette No. 31/13.04.2007.

8. Department of ethical studies. Institute for the study of societies and knowledge - BAS. Available in Internet from: https://ethicsissk.wordpress.com/

9. UNESCO. Global Ethics Observatory. Available in Internet from: http://www.unesco.org/new/en/ social-and-human-sciences/themes/global-ethicsobservatory/

10. Aleksandrova S. Experience in ethical decision-making and attitude of regional hospital physicians towards ethics consultation. In: Schildmann J, Gordon JS, Vollmann J, eds. Clinical Ethics Consultation: Theories \& methods - implementation - evaluation. England: Ashgate; 2010:175-187.

11. Aleksandrova S. Survey on the experience in ethical decision-making and attitude of Pleven University hospital physicians towards ethics consultation. 
Medicine, Health Care and Philosophy. A European Journal 2008;11(1):35-42.

12. Kovacs L. Implementation of clinical ethics consultation in conflict with professional conscience? Suggestions for reconciliation. In: Schildmann J, Gordon JS, Vollmann J, eds. Clinical Ethics Consultation:
Theories \& methods - implementation - evaluation. England: Ashgate; 2010:65-77.

13. Reiter-Theil S, Mertz M, Schurmann J, et al. Evidence-competence-discourse: the theoretical framework of the multi-centre clinical ethics support project METAP. Bioethics 2011;25(7):403-12.

\section{Развитие биоэтики и клинической этики в Болгарии}

\section{Силвия С. Александрова-Янкуловска}

Кафедра наук общественного здравоохранения, Факультет общественного здравоохранения, Медицинский университет - Плевен, Болгария

\author{
Адрес для корреспонденции: \\ Силвия С. Александрова- \\ Янкуловска, Кафедра \\ наук общественного \\ здравоохранения, \\ Факультет общественного \\ здравоохранения, \\ Медицинский университет - \\ Плевен, ул. Климент Охридски \\ № 1, 5800 Плевен, Болгария \\ E-mail: silviya_aleksandrova@ \\ hotmail.com \\ Тел: +35964884196
}

\section{Дата получения:12 января}

2016

Дата приемки: 06 октября 2016

Дата онлайн публикации: 09 января 2017

Дата публикации: 27 марта 2017

Ключевые слова: биоэтика, Болгария, клиническая этика, клиническая этическая консультация, МЕТАР метод

\section{Образец цитирования:}

Aleksandrova-Yankulovska SS.

Development of bioethics and clinical ethics in Bulgaria.

Folia Medica 2017;59(1):98-105. doi: 10.1515/folmed-2017-0015
Введение: Биоэтика и клиническая этика ведут своё происхождение из классической медицинской этики 70-ых годов 20 века. Обе области являются новыми для болгарской академической традиции.

Цель: Целями настоящего труда являются дифференциация предметных областей медицинской этики, биоэтики и клинической этики, представление инноваций в области медицинской этики в Болгарии, выявление трудностей перед эффективным обучением этике медицинских специалистов и демонстрация результатов применения адаптированного метода „снизу-вверх" для клинической этической консультации в ряде клинических объектах в Болгарии.

Материалы и методы: Тщательное ознакомление с литературой и применение адаптированного МЕТАР метода для клинической этической консультации в шести клинических объектах в северной Болгарии в период с мая 2013 по декабрь 2014 года.

Результаты: Преподавание медицинской этики в Болгарии введено в 90-ых годах 20 века и всё ещё включает в себя в основном теоретические знания без достаточного обучения, связанного с данной дилеммой в клинических условиях. Исследования на более раннем этапе обнаружили необходимость В услуге клинической этической консультации в нашей стране. МЕТАР метод был использован в течение 69 этических консультаций. В 31.9 \% из них соображения немедицинского характера повлияли на выбор лечения и в $34.8 \%$ из случаев привели к нахождению консенсуса между медицинским персоналом и пациентом. Мнение участников о консультациях являлось исключительно позитивным с чувством удовлетворения у $87.7 \%$ из них.

Заключение: Развитие биоэтики в Болгарии следует современным мировым тенденциям. Некоторые из идей могут быть использованы для повышения эффективности обучения этике. Результаты этических консультаций приводят к заключению о том, что оно является успешным и хорошо принятым подходом к клинической этической консультации с потенциальными возможностями более широкого применения в нашей медицинской практике. 